\title{
An Inquiry into the Algerian Massacres
}

Youcef Bedjaoui, Abbas Aroua, Meziane Ait-Larbi, eds. Geneva: Hoggar Books, 1999. 1,473 pages.

The book under review offers a monumental, exhaustive and judicious account of "who are the agents behind the "horrendous violence" that has followed the consolidation of the military over incumbent authorities?" The answer provided by the victors, those with the power to institute their choic es and interpretations, is that the paroxysm of "Islamic fundamentalism" is exacting grisly, gratuitous and ghastly violence on a society they have been unable to conquer. On the contrary, scholars insist the beneficiaries of the resource rich regions of Algeria, largely unscathed in the carnage, are indicative of the faceless murderers behind the monstrosity. Moreover, the primary importance of these resources to foreign states and corporations indicates complicity. Amidst this confusing scenario, An Inquiry into the Algerian Massacres provides a clear analysis of the beastly culprits.

Major international human rights organizations and outstanding journalists have not found the "Islamic fundamentalist" argument compelling and continue to raise the same question: "Who is behind these grisly atrocities?" The evidence unearthed strongly suggests that the unseen hands, responsible for the bloodbath, belong to the Algerian army. In addition, striking corroboration has come from defectors and victims which incriminates the Algerian military apparatus and such foreign co-conspirators as the French govemment. This allegation is firmly supported by the environs of the savagery, taking place in close proximity to military and police installations, yet raging for long periods with no interference.

Further disturbing, this charge against the Algerian authorities becomes increasingly credible against the backdrop of the hideous record of rape, torture and mutilation perpetrated by Algerian military authorities, well documented by independent human rights monitors and reputable reporters. Noam Chomsky, in his insightful foreword to the book, collaborates this 
damning reality with the testimonies of defecting secret agents, who insist that not only were the massacres in Algeria organized and undertaken by the Algerian army and secret services, then attributed to the "Islamic Fundamentalists," but so were the bombings in Paris in 1995, with the covert collusion of French authorities. Clearly then, although the belief that the "GIA, Groupe Islamique Arme, an Islamist insurgent group, is widely accepted as responsible for the bloodbath, this belief will be shown to be actually false (B. Izel, J.S. Wafa and W. Isaac, "What is the GIA?")

This troubling and somber study indulges in little speculation. With grim clarity, it keeps to careful documentation of the economic geography of the mass killings, the choice of victims, the locations relative to military and police installations, the timing relative to inter-factional hostilities within the military and other events of political significance, such as the elections and statements, positions and attitudes of France and the US.

The book is broad in scope, bringing together approaches, analyses and information from a variety of fields. Academics and human rights activists in North Africa, Europe and the US contributed insights into the massacres from their many different perspectives. In addition, the book provides a useful chronology of events beginning in $6430 \mathrm{BC}$ and progressing towards more detailed accounts until September 1999, with emphasis on colonial massacres from June 1830, when the French colonialists landed at Sidi-Fredj, onwards to July 1962 and the expulsion of the colonizers. Within the manuscript, the collections of papers divides into seven self-contained parts.

Part I reviews the human rights situation in Algeria and assembles a large amount of data about the massacres and the victims, and poorer segments of Algerian society. The majority of the Algerian population, bitter and disgruntled, with no economic strength, social status or political power, are frustrated with their condition and lash out against those with power, often by means of violence. Similarly, the scholars pose the question "Why would the Islamists massacre their own support base?" The data analysis is carried out from both a statistical perspective and a testimonial approach.

Part II is devoted to a critical analysis of questions pertaining to the motivations and identity of the perpetrators involved in the slaughter. Devoting particular attention to the dominant theses put forward, the inquiry suggests that the crisis is either an Islamic retributive campaign, an expedient tool for inter-factional hostilities within the army, an eviction tactic for land privatization, the settling of family and tribal scores, or a counter-insurgency military tactic. In conclusion, the chapter alleges the paternity of the 
Algerian military hierarchy over the GIA. The focus is on the identity of the mysterious and murderous GIA, stating that it is a counter-insurgency group controlled by the Algerian military with covert assistance by French secret services.

Part III focuses on how the government, political parties and society at large respond to the massacres and why. The author, J.T. Senhadji, concludes that " $[t]$ he majority of independent parties, organizations or personalities suspect the military regime of involvement in the massacres in one form or another." This section of the population collectively favors the establishment of an international commission of inquiry into the massacres and violations of human rights so that the perpetrators may be unambiguously identified. Sadly, the Algerian authorities continuously refuse an international inquiry to corroborate their claims of an "Islamic fundamentalist" connivance.

Part IV addresses the response of the international community, as represented by states and international organizations, towards the massacres. Analysis focuses on French, US and Arab-Muslim reactions to the atrocities. French reactions are pitiful, particularly since establishment figures and intellectual journalists accuse the Islamists, while insisting an independent assessment is unnecessary. However, L. Salem-Badis argues that "French scholars and researchers accuse the regime of masterminding and manipulating the violence for its own survival." US reactions to the killings have explicitly condemned the killings, siding with the Algerian military junta, though reminding the leadership of its responsibility to protect its population. As of now, US official policy has shifted towards the Algerian military government and insightful voices calling for an independent inquiry have been rescinded. Arab-Muslim opinions have been equally unclear, either in complete support or total aversion to the Algerian military leadership. Interestingly, this section of the book points to the futility of Arab regimes, suggesting they will only help each other muzzle political opponents and critics.

Part V looks at the massacres in Algeria from an historical angle with focus on French colonial massacres. As a corporal in the $2^{\text {d }}$ Battalion of foreign paratroopers said, "If there were one day to be another Nuremburg Trial, we would all be condemned: Oradour, we do the same every day in Algeria.' Although the massacres in Algeria are unique, their frequency, scale and extent have precedents and analogues in Algerian history. Therefore, a history of past atrocities during colonization should contribute to an understanding of the current atrocities. 
Part V also relays the strategic, tactical and retributive instrumentalities that underlay the massacres. Clearly, the colonial massacres were not senseless actions devoid of reasoning from the point of view of the conquerors. Coercion was utilized as a colonial instrument during different stages of colonization and was conscientiously studied and planned. The use of violence was a bloody expression of colonialism, punitive measures and depopulation leading to land reallocation.

Part VI is concerned with the criminal status of the massacres in Algeria's internal law, their categorization in international criminal law and the issues of investigation, prosecution and punishment of those responsible for them. This section consists of three papers, written in French, by the Algerian jurist, Ibrahim Taha. The author argues that "Algeria's internal criminal code does not provide for the recognition, prosecution and punishment of the current massacres that are part of a deliberate and systematic policy pursued by the state ("L'indifference du droit Algerien aux massacres.")

In conclusion, Part VII displays a photographic account, based on world press photos, of the Algerian calamity. The scale of the Algerian massacres and the sadistic brutality has shocked the entire world. Words and numbers have partly captured these unspeakable crimes, bringing home the horror and suffering of tens of thousands of innocent men, women and children.

The relevance of this comprehensive analysis, in An Inquiry into the Algerian Massacres, finds fertile soil in all disciplines of the social sciences. From those who wish to examine the impact of colonization on a subjugated people, whether that coercive influence is socio-political, economic or religio-cultural, the wealth of information is impressive. Still, in the discipline of political science, the account provides outstanding insight into the dynamics of French control and conquest. Particularly significant were French colonial attempts to discredit Algerian Muslim norms, values and tradition. Similarly, sinister colonial maneuvres that exacerbate differences between the Arab and Berber peoples were pivotal in maintaining their hegemony. Yet, the main argument of the book is to assess who is behind the massacres of innocent Algerian civilians. A comprehensive study with careful documentation and thorough analysis provides a powerful damnation of the Algerian military junta, their co-conspirators within French intelligence services, and all who turn a blind eye to the haunting scenes of bloodshed. 